\title{
GUARDING SHARIA ECONOMY IN INDONESIA OPTIMIZATION OF CONTEMPORARY ULAMA AUTHORITY AND LOCAL WISDOM
}

\author{
Muhammad Djakfar \\ Fakultas Ekonomi Universitas Islam Negeri Maliki Malang \\ Email:mdjakfar@yahoo.co.id
}

\section{Abstract}

Sharia economy is one of the economic system, in addition to the other two systems namely capitalist and socialist. Although the socialist system is no longer popular at the global level, but in reality the Sharia Economy system is still outdone by the secularistic capitalist system. In practice, the capitalist system contains many weaknesses so that the world community began to look for other systems as a solution, namely sharia economy. In Indonesia the development system is relatively slow, so it is necessary to optimize the role of ulama and the function of local wisdom. This is the literature research with data sources from various literature and relevant issues. The results of the study show that with its authority, contemporary ulama can perform the role as a giver of fatwas, enlighteners, thinkers and economic actors. Enlightenment can be done through religious or educational events, while business practices can be conducted in pesantren by developing businesses, all of which are part and function of local wisdom.

Ekonomi syariah adalah merupakan salah satu sistem ekonomi, di samping kedua sistem yang lain yakni kapitalis dan sosialis. Sekalipun sistem sosialis akhirakhir ini tidak lagi populer di tingkat global, namun dalam kenyataan sistem ekonomi syariah masih kalah cepat dengan sistem kapitalis yang sekularistik. Dalam praktiknya, sistem kapitalis mengandung banyak kelemahan sehingga masyarakat dunia mulai mencari sistem lain sebagai solusi, yakni ekonomi syariah. Di Indonesia sistem ini perkembangannya relatif lambat sehingga perlu mengoptimalkan peran ulama dan fungsi kearifan lokal. Wacana ini 
merupakan penelitian pustaka dengan sumber data dari berbagai literatur dan isu yang relevan. Hasil kajian menunjukkan bahwa dengan otoritasnya, ulama kontemporer dapat melakukan peran sebagai pemberi fatwa, pencerah, pemikir dan pelaku ekonomi. Pencerahan dapat dilakukan melalui acara keagamaan atau pendidikan, sedangkan praktik bisnis dapat dilakukan di pesantren dengan mengembangkan usaha, yang semuanya itu merupakan bagian dan fungsi dari kearifan lokal.

Keywords: sharia economy development; optimization of contemporary ulama authority; local wisdom

\section{Introduction}

Recently, the sharia economic system has begun to be widely adopted and developed by various countries in the world. One of the indicators is that even secular countries are starting to develop Islamic banking and halal tourism, both of which are the embodiments of the sharia-based economic teachings with the main sources are the Quran and Sunnah of the Prophet saw. In relation to the banking business for example, Britain is said to be ambitious to become the center of world-class Islamic finance. It seems that they are beginning to understand that the sharia system is more justice and safer than the threat of humanity tempest caused by the capitalist system that has dominated the practice of the global economy.

Similarly, in the world of tourism, Taiwan, South Korea, Thailand and Japan for example, they have begun to engage in a well-known tourist industry with Muslim tourists (Republika, May 12, 207, 9; Republika, May 12, 2017, 18-19). In business, these countries have been able to calculate that in the future the halal tourism industry will be profitable economically. Based on the 2016 Globalcard-Crescent Rating Global Muslim Travel Index (GMT) study, the total number of Muslim tourists worldwide reaches 117 million by 2015. The number is expected to grow to 168 million tourists by 2020, with spending above 200 billion dollars (Republika, May 12, 2017, 9).

Of the two kinds of banking and tourism business above, until now the position of Indonesia is still far behind those countries. As the largest Muslim country in the world, Indonesia must be the forefront and should be a Mecca of sharia economic development in the global level. Does not Indonesia have little potential and carrying capacity that can be explored and developed? Among others, its large numbers of the population (about 255 million people) and 
natural wealth are so abundant. Both of these power sources are very potential carrying capacity for the vital national economic development.

However, in reality, especially for sharia banking, for example, until now in Indonesia only has a market share of about five percent of the amount available. Practically, the rest is still dominated by the riba of conventional banks. Similarly, related to the tourism industry so far obtained by Indonesia is still not too large as expected.

This fact is certainly an irony that should not be sustainable, and at the same time a challenge for the government as the stakeholders as well as for the ulama who have moral responsibility to guard all activities of sharia-based industries in Indonesia.

In this case, the ulama have a very strategic role to teach the sharia rules related to the world muamalah (business industry), because the authority of science. Moreover, sociologically, they hold a respectable position in society so their fatwa become a lot of reference. According to Mohammad Iskandar, a Professor of History at the Faculty of Cultural Sciences of the University of Indonesia, "The fatwa of a kiai is much more heard than a bupati's appeal by society." Even in many cases, he argued again, the problems faced by society cannot be answered by bupati (regency major), but can be answered by the ulama (Republika, May 14, 2017, 17).

The central position of the ulama among the ummah, especially the Muslim community in the countryside, is so high and honorable. This kind of attitude is respected to be part of local wisdom that has long existed in Indonesia. Indeed, the position of ulama in the middle of Muslim community is the front buffer of the existence of local wisdom that developed in the community. A few religious traditions are still alive among the people who need their presence, for example in tahlilan event, aqiqah, the marriage ceremony, hajj departure event (hajian) and others that always presenting tausiyah (religious speech) of da-i of the ulama. Thus, the position of the ulama is a vein, as well as the strength of the continuity of local wisdom in various places.

This is one proof that however in reality there is a touch between the role of ulama and the growing local wisdom among Indonesian Moslems. Even the enthusiasm of the community to send their children to pesantren educational institutions in Indonesia is also a part and local wisdom that continues to survive until the modern century.

Therefore, the institution of local wisdom that is nuanced religiosity as mentioned above is a medium of teaching about Islam to the wider community 
which actually became part of ulama role. The lessons which should be taught are iman (faith), Islam, and ihsan. Moreover, the teaching of Islam is not only a matter of worship, in the sense of teaching the relationship between man and his God (vertical), but also concerning the relationship between human beings (horizontal), such as, economic activities to meet the needs of human life.

Therefore, the focus in this article is how contemporary ulama can play a role in promoting the development of sharia economy in Indonesia in accordance with the authority that they possess. To make it more intensive and effective, the activity should be done through various religious activities which is the potential of local wisdom that is still alive in the community that needs to be utilized optimally.

In accordance with the focus, this article is a literature study with data (materials) extracted from various relevant literature sources (documentation), both in the form of manuscripts (references-maraji ') and discourses or issues published in the media.

The collected data are then analyzed critically, reinforced by theories or opinions of competent experts: Nikki R. Keddie, Iik Arifin Mansurnor, Hiroko Horikoshi, Kuntowijoyo, Muhammad Syafii Antonio and M. Quraish Shihab. From the analysis, it is expected to get a formulation of discourse of ulama participation which is more concrete through utilizing the potential of local wisdom that contributes the development of the future sharia economy in Indonesia.

\section{Sharia Economics as a Solution}

The development of sharia economy has developed quite rapidly. This development is not only in various countries based on Islamic sharia as in various countries in the Middle East or the majority of Muslim population such as Indonesia and Malaysia for example, but also began to penetrate to various secular countries that are not politically and culturally untouched by the principles of sharia, such as England, Italy, Hong Kong, China (Republika, May 17, 2009).

Secular state societies in the region of Europe have recently begun trying to design to implement the non-riba economic system. It seems that they are beginning to understand that the uluhiyah-rabbaniyah system really puts forward real justice and puts forward the value of humanity in the Economics world. They start to make sharia economy as one of the subject, specifically in Islamic Studies which can connect Islam and Western (Republika, October 
8, 2017: 16). In addition, it is also applied in the business world (corporates). For example, the British state is now ambitious to be the center of Islamic finance at the world level as has been mentioned in other parts of this article.

Presumably, the global economic crisis that often affects many countries in the world has changed the worldview of the sharia economy which is considered more attractive, simple, universal, and very profitable (Antonio, 2009: iii-iv). Even in times of worst global crisis, the sharia system remains stable which in this case can be seen and the performance of sharia banking that is not affected by any crisis (Antonio, 2009: iii-iv).

Therefore, Budiono, former Governor of Bank Indonesia and former Vice President of the Republic of Indonesia declared:

"Sharia economy could be the key for Indonesia to be exit from the impact of the current global financial crisis. One of causes is that the non-riba-based economic system is a real pro-sector." Sharia economics is a serious option for our economy compared to conventional systems, transactions in sharia economic systems are based in concrete economic activity, which is different from the conventional system that may base its activities on derivative transactions' (Republika, June 9, 2009).

Absolutely, in accordance with the evolving reality, Budiono's opinion is still relevant. Therefore, to encourage the growth and development of Islamic banks, according to Antonio, the strategy should be proposed is to promote the concept of halal, more elastic, cooperative system that can encourage small and medium enterprises (Antonio, 2009: iii-iv). Therefore, according to Antonio, for Islamic banking continues to grow, it should continue to increase and improve its performance to look more and more Islamic. The teachings of Islamic economics should not be understood only on the level of the contract, but also at the level of value (Republika, June 11, 2009: Djakfar, 2015: 12).

However, it should be realized that the economic progress of a country cannot be separated from the business progress. Business activity is the main engine that will carry the carriage of economic progress of a nation (Djakfar, 2015: 13). In other words, the business activity is similar with real sector that determines the economic progress of a country when it is associated with conventional Economics (Panggabean, in Republika, 18 April 2007). This has become a common opinion, as well as an indicator, that the economic progress of China, Japan, South Korea, Singapore and others cannot be separated because of the real sector movements conducted by small and medium enterprises in their countries.

el Harakah Jurnal Budaya Islam Vol. 19 No.2 Tahun 2017 
Nevertheless, if we have a strong intention to make sharia-based Economics as a system of economic solutions in Indonesia, however, all business activities carried out must always be in the atmosphere of Rabb's guidance sourced from the teachings of revelation, namely the Quran and Sunnah of the Prophet saw (Djakfar, 2015: 13). The trick is to stay in the behavior and mindset of the subject as his locomotive, namely the behavior that is bound or has a strong commitment to the Illahi Rabbi's teachings (aqidah) (Djakfar, 2015: 13).

Above all, the faith can engage a person's heart about what is believed - that Allah swt is the Almighty God who must be obeyed by all His creature, including in economic matters (Djakfar: 2015: 14). The engagement seems to be inextricably linked with the concept of istikhlaf which places man as the representative of God, as well as prospering on the face of this planet (Djakfar, 2015: 14, Qardhawi, 1995).

In Indonesia the implications of this sharia system is not only limited in the form of sharia banking that has been more widely known by the public, but also manifested in the form of other business institutions such as pawnshops, insurance, capital markets, cooperatives, and so on, all of which are guided by the sharia principle. Lately, in accordance with global trends, in Indonesia also began to penetrate the world of tourism industry, hotels, restaurants, and travel which basically aims to anticipate market demand, in this case the Muslim tourists, both domestic and abroad.

Especially for halal tourism, the Indonesian government should work seriously as a halal industry with truly professional, so that our country can win the competition at a sharper global level. This industry hopefully will be able to give the most important foreign exchange for the country after other sources such as oil, gas, and coal that began to thin out or even been over to be explored.

\section{Ulama, Local Wisdom, and Economics}

As a country with the largest Muslim population in the world, Indonesia has many experts in the field of religion, in this case Islam, which is generically known as the ulama. However, in line with so many ethnic groups that exist, the title of the religious scholar that causes unequal nicknames between regions with one another. It seems that the respective nicknames are the impact of the local wisdom process of each region though and the substance is the same thing that is a figure recognized by the community as a person who mastered the science of Islam. 
In a local perspective, in West Java, they are called by Ajengan, while in Central Java and East Java, called Kiai. The title of Kiai in these last two areas as an honorary title given by the people to someone who is an expert in the field of Islam who generally lead boarding school (pondok pesantren) and teach the classical Islamic books to his pupils (santri) (Dhofir, 1982: 55; Arifin, 1993: 14 ). However, among the Maduranese who are known to be religious, the title of the cleric is called "keyae" which generally has or leads a boarding school. However, a person of Madura can also get the title of keyae because of lineage (Djakfar, 2009: 133, Mansurnor, 1990: xix-xx).

The role of kiai or religious teacher (read: ulama) in Madura is very dominant. The institutionalization of kiai and religious teachers is pesantren or langgar (mushalla) (Kuntowijoyo, 1993; Anwar, 1996). They seem to be working to keep the religion of the people. Religious culture (local wisdom) is a culture that, influenced by a religion that manifests itself in the form of spirituality, ethics and symbols (Anwar, 1996). As long as pesantren is still needed by the community, however, the role of religious leaders (ulama) will still be great (Anwar, 1996). And in this pesantren, ulama can continue to develop the values of spirituality and ethics in doing muamalah (economic) and even can actualize in the form of building business (uswah) in real terms in each environment.

In another Muslim-majority region, the title is different. For example in West Sumatra, known as Buya. While in Aceh which is famous with the nickname Serambi Makkah, someone who is knowledgeable enough religion called the title Tengku. In Lombok, West Nusa Tenggara - known as the island of a thousand mosques - people who have competence in the science of religion and pesantren is usually called as Tuan Guru (Master Teacher). There will so many variations of predicate for every person who has the knowledge of Islam in various regions of the archipelago, so they are respected and considered to have authority in the form of religious roles in the community.

The number of titles given to ulama in each of the above areas indicates that the prophet's heir has a respectable position in every Muslim region. It also indicates that there is a relation between ulama and local wisdom and they perform their main function in daily life. In this case, the ulama act as a buffer of solid local wisdom in each region. Because without the support of the ulama, especially those that touch religious life, it is impossible for local wisdom to survive, especially in the modern era today which is not infrequently there has been a shift in secularistic values.

el Harakah Jurnal Budaya Islam Vol. 19 No.2 Tahun 2017 
Many parents in Indonesia entrust their children to be educated in various pesantren, both salaf and modern. In reality, this habit of sending children to the pesantren has long been going on for generations and has become part of the local wisdom of the Muslim community in Indonesia. This is one of the unique characteristics of the Muslim community in Indonesia that often prefers religious education rather than general education which seems to have become a worldview for them, especially after pesantren in Indonesia try to integrate religious curriculum with a general curriculum which in the end this educational institutions is increasingly to be the choice of the wider community. The local wisdom is a very long process and then become a philosophical reference and the guidance of a society (Fitri, 2012: 2).

As has been mentioned previously, the stakeholders of pesantren education institutions in Indonesia are the ulama (Republika, May 14, 2017, 17). This institution of course, in accordance with its function, can be used as a media or infrastructure to conduct socialization related to economic issues to the wider community, in addition to its main function of teaching religious issues.

This is presumably the main pillar of sustainability of local wisdom that has long been the source of the way of life for a certain community in society. Absolutely, the form of expression rather than local wisdom is not limited only in terms of educational issues alone, but also touches the domain of birth, marriage, economic, social, religious, and so forth.

The concrete form of expression is generally packed in the form of a religious event (spiritual) so it is not uncommon to involve the role of the ulama as a lightening member who becomes part and main authority in society. And here finally it is understood that there is such a strong relationship between the authority of ulama, local wisdom and economic development.

For that reason, the true authority of that role for contemporary ulama has not been entirely limited to preachers, preachers and teaching books of turats as they were before. But in today's modern world they should be able as well as thinkers and thinkers in contemporary problems and be able to actualize it in the real world.

\section{The Strategic Role of Ulama: Reinforcing Authority}

According to Nikki R. Keddie, ulama are seen as a group of respected people, who have a number of personal and corporate wealth and have a great influence in shaping Islamic society. The ulama has a duty as a lecturer, preacher, or qadi, even receiving an appreciation for his services in various 
forms (Keddie, 1978: 2). He further argues that ulama are not only managing a certain amount of wealth, but also have influence as a guardian in the field of law, learning, and religious orthodection. In addition, they also manage educational institutions from basic level up to universities, judiciary, hospitals, and other charitable institutions (Keddie, 1978: 2).

Therefore, by referring to Keddie's opinion, it can be concluded that the ulama's authority is not only a matter of religious (spiritual), but also touches the contemporary realm needed by the people. In other words, the presence of ulama in their midst is so urgent (meaningful) because of its strategic and multifunctional role. Ulama. In addition to its main duty as a guardian of belief, but in reality they can serve as a place of community consultation in all aspects of life. For example in political issues, social relations, family, health, economy, and so forth (Djakfar, 2015: 229).

Furthermore, in relation to that role, the ulama task is to provide guidance and instructions to overcome disagreements, social problems that live and thrive in society (Shihab 1993: 375). Among other things is the problem of sharia-based economic development needs as a solution to overcome the economic problems that twist the society today in the mid of domination of capitalistic economies in various parts of the world.

Thus, the presence of ulama in the Muslim community, especially among the traditional people who are mostly domiciled in the countryside, is like a supermarket that provides everything the people need. It means that they will come to kiai to consult their various problems. Among other problems mate, santri community usually ask for prayer and blessing from their kiai (Djakfar, 2015: 229). It is often found that the students visit their kiai in their previous pesantren just for asking his blessing on their new business. They believe that kiai's blessing will bring luck in their project.

According to Hiroko Horikoshi, the ulama relationship with the village community is called by the term of patron with the client. According to him, many factors that cause the closeness between the patron with the client, among others because of its scholarship and moral credibility, in addition to the ulama as community protector (Horikoshi, 1987: 148-188). In the face of society, in various regions, ulama are seen as consultants, both with regard to religious spiritual issues as well as worldly issues.

Therefore, in the eyes of the people, especially in the rural environment so far, ulama (kiai) still have a great influence on the ummah. Thus according to M.A. Mannan, ulama need to be involved in development. Among others 
participated in the socialization of agriculture as conducted by church leaders in the United States (Mannan, 1995: 390). Of course this task can be done by the ulama in Indonesia as close to the community in all social status.

Furthermore, it seems that the strategic role was felt by Sudanese people some time ago during the economic crisis with inflation figures up to three digits. Therefore, we can learn from the Sudanese nation as one of the countries in the Middle East that the implementation of sharia economy can be said to be advanced. In fact, the entire banking system has adopted the total sharia system (Bakhri, 2004: 72).

In this correlation, according to Ahmad Ali Abdalla, a Sudanese Islamic banking expert, the ulama in Sudan take a very important role in the application of sharia economy and banking as a solution of the economy and riba banking (Bakhri, 2004: 72). A key accomplishment after Sudan implements sharia economic and banking system is the increase of national economic growth which reaches an average of six percent per year (Bakhri, 2004: 72).

More concretely, how the role of ulama in developing a sharia-based economy. In this case, as stated by Muhammad Syafii Antonio, among others related to the problem of supervision, socialization, and product development (Antonio, 1999: 283-289). The first role is supervision, as is done by the Sharia Supervisory Board (DPS) and the National Sharia Board (DSN). DPS is in charge of making pesantren regularly that its supervised bank has been running according to sharia provisions, as well as making new product recommendations from supervised banks.

While the duty of DSN, serves to oversee the products of Islamic financial institutions in accordance with the provisions of sharia. Even this council also oversees other institutions other than sharia banking (Antonio, 1999: 283289). In addition to studying, complaining of fatwas, and recommending who will be assigned as DSN members (The set of Fatwa of DSN-MUI, 2006 \& 2010). In addition also entitled to give warning against financial institutions that deviate from the provisions of sharia (The set of Fatwa of DSN-MUI, 2006 \& 2010).

The second role, to socialize, among others contributed to explain to the public that sharia banking is basically the application of the fiqih muamalah maaliyah. While the third is the intended product development, according to Syafii, at least the ulama play a role to absorb the aspirations and financial needs of the ummah. Further it is formulated with the management of Islamic banks and disseminating them to the community (Anonymous/The set of 
Fatwa of DSN-MUI, 2006; Anonymous/ The set of Fatwa of DSN-MUI, Volume 2, 2010; Djakfar, 2015: 229).

Based on the above description, it can be understood that the role of ulama is as strategic as possible in the development of revelation-based economic, as is done in Indonesia as well as international experience, such as in Sudan. Even in the United States, known to the Christian majority, it is also done by religious leaders, in this case church leaders to promote agriculture that can drive their economic progress.

\section{Roles Actualization}

The ulama in performing their role can do it verbally (lisanul maqal), in addition to the form of an example of deed (action-lisanul hal). With the first method of the ulama through speech in places of worship in various events. Or through routine recitation in various community of ta'lim assembly and religious events that exist in the community. Even the speech can also be in classroom through teaching and learning process of yellow book (turats) in pesantren and madrasah (religious-based school). Through these various ways, the ulama can explain how true sharia-based economics is part and the teachings of muamalah in Islam. By this way means the ulama in socializing sharia economy is only a theoretical-normative that can be used as a theological basis to apply it in the real world (real) in the community.

However, such normative forms of teaching (socialization) have not yet been enough to make the people understand, because they still need to be given a real example (uswah). The method brought by Rasulullan saw covers two aspects, those are hadis (Prophet saw's saying) and uswah (Prophet's exemplary action).

In other words, in the teaching of economic matters (muamalah), Rasulullah saw does not only do the verbally theoretical-normative, but he also practices it directly how to do business in accordance with the guidance required in Islam. Even recorded in history, the duration of his time in the business world (tijarah) reaches approximately 25 years (Djakfar, 2012: 329., Alzalurrahman, 1982). Beyond the duration of doing his nubuwah/mission for approximately 23 years can be categorized into two phases. The first phase is known for the period of Makkah (about 10 years) which teaches a lot of tauhid (faith) so that the people of Jahiliah will worship only to the One God, Allah Almighty. While the second phase is known as the Medina period (about 13 years) which teaches a lot about muamalah.

el Harakah Jurnal Budaya Islam Vol. 19 No.2 Tahun 2017 
The ulama as the heirs of the prophets, it is fitting for them to follow in the footsteps as practiced by the Messenger of Allah. That is, in terms of economic problems, they are in reality, not limited to teaching verbally, but also need to practice it directly in the middle of the wider community. Currently the ulama are beginning to realize that in reaching the world of education for example, must be supported by adequate financial independence. If not, it is difficult to develop all educational programs that built maximally because of constrained funding factors that are less supportive.

Such a strategy has been exemplified by Rasullah and his Companions. Sayyidah Khadijah ra was a wealthy merchant who became known as a conglomerate of Mecca in his day. However, the wealth is not solely for the benefit of himself and his family, because most of them to back-up the struggle of the Prophet in teaching Islamic sharia. Similarly, the Messenger of Allah himself as a trader is also including the rich, as well as his companions. Of course, that his possessions were merely a mandate. They also understand that in essence his wealth belongs to God alone. That's why they confers all his wealth is for jihad in the way of Allah swt in the struggling for Islamic Sharia.

Presumably in the effort to follow uswah Rasulullah saw, not a few ulama (kiai) in Indonesia who perform the business world, both individually and institutionally on behalf of pesantren of their management. Nowadays it is not a small pondok pesantren that develops its business. The business they developed is not in the form of conventional business that is lacking or even without a system, professional management. But in fact, they are able to develop modern businesses such as supermarkets, cooperatives, gas stations, and so forth that can be observed by unassisted eye.

Among the pondok pesantren that can be an example is Pondok Pesantren Sidogiri Pasuruan East Java, Pondok Pesantren An-Nur Bululawang Malang Regency, and Pondok Pesantren Assirojiyyah Sampang Madura (Djakfar, 2015: 235-242). The order of this pesantren illustrates the amount of business developed so far to achieve economic independence. Absolutely, there are still many pesantren who have businesses that are not raised in this discourse.

Therefore, based on the above facts, it seems that the pesantren entrepreneurs feel not enough just to teach science and encourage Muslims for entrepreneurship that is only normative. But it should also be followed by uswah (bilhal) as the implementation of Islamic teachings in concrete that must be real grounded in life. 
In other words, that the participation of ulama is not only teaches normatively, but they also practice the doctrine in the real sector. At the same time trying to cadre their students to have insight and experience in the world of commerce (entrepreneurship). This is the true contribution of salafi pesantren that should be appreciated in support of sharia-based economic development in Indonesia in the future. And with the role played, society and the Government should give a high appreciation to the pesantren through the care of the ulama who have become the "agent" of real sector development in order to support the progress of sharia economy nationally.

Furthermore, in terms of his duty as a guardian of the problem, the law, ulama who joined in the DSN-MUI until 2016 has managed to produce fatwa as many as 108 units. The last is about the Guideline of Tourism Based on Sharia Principle No.108 / DSN-MUl / X/2016. The existence of this product will certainly strengthen the development of halal tourism industry in the country as an implication of sharia economic values idealized and taught.

Furthermore, in relation to the role of ulama in the effort of developing sharia economy is to socialize the results of his thoughts in the form of written works. Among these are Didin Halidhuddin (Djakfar, 2014: 163189), Adiwarman A. Karim (Djakfar, 2014: 189-217), Muhammad Syafii Antonio (Djakfar, 2014: 217-239), and much more. These three experts are as representatives of contemporary ulama who are very competent in the field of Islamic economics, his writings have long and many references, both in, academics and practitioners, therefore their services need to be appreciated.

\section{New Flow of Indonesian Economics: Initiating Sharia-Based Solutions}

The ulama who joined in the forum of the Indonesian Ulama Council (MUI) on 22-24 April 2017 have held the People's Economic Congress (KEU) with the main mission to build a new economic flow of people in Indonesia. This Congress needs to be held because the ulama see the economic condition of Muslims who are objectively still apprehensive, so it needs to find a solution. Indonesia is as a country with the largest Muslim population in the world, in fact is really it turns out the economic cake has not been able to be controlled by Muslims themselves. (Republika, March 31, 2017, I, Amin, 2017).

According to the projection of the MIDI Economic Empowerment Commission, so far the economic wealth of Muslims is still less than 20 percent, although the number of Indonesian Muslims reaches more than 80 percent of the total number of people (Republika, 31 March 2017, 1). Even on the 
basis of Oxfam's report, in the last two decades, inequality in Indonesia has increased more rapidly than other countries in Southeast Asia. As reinforced data suggest that the collective wealth of the four richest people in Indonesia reaching 25 billion US dollars (equivalent to Rp. 335 trillion) is far greater than the total wealth of 100 million people in Indonesia (Republika, 31 March 2017 , 1). Of course this worrying condition cannot be sustained, but it needs to be initiated to further execute the solution.

According to the projection of the MIDI Economic Empowerment Commission, so far the economic wealth of Muslims is still less than 20 percent, although the number of Indonesian Muslims reaches more than 80 percent of the total number of people (Republika, 31 March 2017, 1). Even on the basis of Oxfam's report, in the last two decades, inequality in Indonesia has increased more rapidly than other countries in Southeast Asia. As reinforced data suggest that the collective wealth of the four richest people in Indonesia reaching 25 billion US dollars (equivalent to Rp. 335 trillion) is far greater than the total wealth of 100 million people in Indonesia (Republika, 31 March $2017,1)$. Of course this worrying condition cannot be sustained, but it needs to be initiated to further execute the solution.

The lack of large Muslim entrepreneurs in the list of the richest people in Indonesia can be trickled by various ways (Republika, 29 Maid 2017, 1), among others, networking and communication (Republika, 29 March 2017, 1). In addition, according to the ulama need to be balanced by changing their mindset, in order to be able to break the dominance of conglomerates from other groups, as well as have the mindset of being rich (Republika, March 29, 2017, 9).

Therefore, based on the real economic condition of the people as mentioned above, the KEU produces declaration points and five recommendations (Republika, 25 April 2017, 1). The seven points are as follows: 1) To affirm a fair, equitable and independent national economic system in overcoming economic disparities; 2) Accelerate the redistribution and optimization of natural resources wisely and sustainably; 3) Strengthening competent and highly competitive human resources based on the benefits of science and technology, innovation, and entrepreneurship; 4) Mobilize cooperatives and micro, small and medium enterprises become national economic entrepreneurs; 5) Creating equal partners of large enterprises with cooperatives and SMEs in integrated production and market system; 6) Mainstreaming of sharia economy in the national economy, still in the framework of Pancasila, 1945 Constitution, 
Bhinneka Tunggal Ika, and NKRI; and 7) Establish an Economic Committee of the Ummah to guard the new economic flows of the Indonesian economy (Republika, 25 April 2017, 1).

The recommendations presented include: 1) The division of duties in collecting data centers and studies of empowerment of the people; 2) Distribution and cooperation in various studies of the economic empowerment of people related with issues of business environment development, both internal and external, national, and global; and 3) The formulation of recommendations of economic action steps of the people that can be implemented in synergy, as a real effort to empower the people's economy (Republika, 25 April 2017, 1).

Among the seven contents of the declaration that should be underlined is to position the sharia economy as a major player of the national economy that is expected to realize justice and economic equity among people who have been far from expectations. This idea of thought will be executed and will continue to be guarded by the ulama as part of their role in building the nation.

\section{Conclusion}

Starting and the above description can be understood that the contemporary ulama actually are not a little role in participating in developing the nation's economy based on sharia. Their strategic role does not seem to be replaced by other communities in Indonesia that still uphold the values of Islamic teachings. In reality, they can perform their roles, both individual (independent) and the structures as compiled within the vessel of the Indonesian Ulama Council. Or, more broadly, they can be gathered also in the religious social community that exists in this beloved country.

In reality, there are not few roles that can be done by ulama in Indonesia according to their competence (authority) in the effort to participate in marketing sharia economic values in the wider community. Among others, to provide enlightenment in the form of maw'idah hasanah (religius speech) through existing local wisdom institutions, as well as tangible legal products, thoughts or also in the form of paper that has been done for so many. Even with bilhal dakwah (concrete uswah) by developing a real business in their pesantren environment.

Hopefully the helping hand of the ulama continues to sustain the future of Indonesia's sharia-based economic that is now being developed in many countries. And with the optimization of the ulama's authority by

el Harakah Jurnal Budaya Islam Vol. 19 No.2 Tahun 2017 
exploiting the potential of local wisdom that has long lived, it is expected that the development of sharia economy in Indonesia, no longer stagnant or slow as it is today. For that reason, the future of sharia economy is expected to accelerate faster, with the support of the entire Indonesian people on the basis of their own consciousness and choice.

\section{References}

Afzalurrahman (ed). 1982. Muhammad: Encyclopedia of Seerah. London: The Muslim Schools Trust.

Amin, K.H. Ma'raf. 2017. Solusi Hukum Islam (Makharij Fighiyyah) sebagai Pendorong Arus Baru Ekonomi Syariah di Indonesia (Kontribusi Fatwa DSN-MUI dalam Peraturan Perundang-undangan RI) (Scientific Oration delivered in the Inauguration of Professor of Economics of Sharia Muamalat, May 24, 2017). Malang: Ministry of Religious Affairs 17), UIN Maliki Malang.

Antonio, Muhammad Syafii, 1999. Bank Syariah Wacana Ulama E Cendekiawan. Jakarta: Tazki Institute.

Antonio, Muhammad Syafii, 2009. Asma'ul Husna For Success in Business $\mathcal{E}$ Life. Jakarta: Tazkia Publishing.

Anwar, Chairil. "Dinamika Kultural Masyarakat Madura," dalarn Ruh Islam dalam Budaya Bangsa Aneka Budaya di Jawa, 1996. Jakarta: Yayasan Festival Istiqlal.

Arifin, Imron, 1993. Kepemimpinan Kiai: Kasus Pondok Pesantren Tebuireng. Malang: Kalimasada Press.

"Atasi Krisis dengan Ekonomi Syariah, " in Republika, May 17, 2009.

Bakhri Mchd, Syaifui. Kebangkitan Ekonomi Syariah di Pesantren: Belajar dari Pengalaman Sidogiri. 2004. Pasuruan: Cipta Pustaka Utama.

“Bangun Ekonomi Umat," in Republika, edition of March 31, 2017.

Dhofir, Zamakhsyari. 1982. Tradisi Pesantren: Studi tentang Pandangan Hidup Kiai. Jakarta: LP3ES.

Djakfar, Muhammad. 2007. Agama dan Etos Bisnis Elit Pesantren Salafiyah: Studi Kasus di Pondok Pesantren Assirojiyyah Sampang Madura, Jurnal Akuntansi-Bisnis $\mathcal{E}$ Manajemen, 14 (3), p. 1-20. 
Djakfar, Muhammad, 2009. Anatomi Perilaku Bisnis Dialektika Etika dengan Realitas. Malang: UIN Malang Press.

Djakfar, Muhammad, 2012. Etika Bisnis Menangkap Spirit Ajaran Langit dan Pesan Moral Ajaran Bumi. Depok: Penebar Plus.

Djakfar, Muhammad, 2014. Agama, Etika, dan Ekonomi Menyingkap Akar Pemikiran Ekonomi Islam Kontemporer Menangkap Esensi, Menawarkan Solusi. Malang: UIN-Maliki Press.

Djakfar, Muhammad. 2015. Wacana Teologi Ekonomi Membumikan Titah Langit di Ranah Bisnis dalam Era Globalisasi. Revised Edition. Malang: UIN Maliki Press.

“Ekonomi Syariah Opsi Serius,” in Republika, June 9, 2009.

Fatwa Dewan Syariah Nasional-Majelis Ulama Indonesia No.108/DSNMUI/X/2016 tentang Pedoman Penyelenggaraan Pariwisata Berdasarkan Prinsip Syariah.

Fitri, Agus Zaenul. Pola Interaksi Harmonis Antara Mitos, Sakral, dan Kearifan Lokal Masyarakat Pasuruan, in el-Harakah, 14, (1), p. 1-12.

Horikoshi, Hiroko. 1987. Kiai dan Perubahan Sosial. Jakarta: P3M.

Iskandar, Mohammad. "Peran Besar Ulama dan Pesantren di Priangan," Republika, Edition, May 14, 2017.

Kuntowijoyo, 1993. Radikalisasi Petani. Jogyakarta: Bentang.

Keddie, Nikki R., (ed). 1978. Scholar, Saints, and Sufis. California: University of California Press.

Mannan, Muhammad Abdul. 1995. Teori dan Praktik Ekonomi Islam, ter. M. Nastangin. Yogyakarta: PT. Dana Bhakti Wakaf.

Mansurnoor, lik Arifin, 1990. Islam in an Indonesian World: Ulama of Madura. Yogyakarta: Gajahmada University Press.

"Non Muslim tak Perlu Takut Syriat Islam, in Republika, April 18, 2007.

"Pengusaha Muslim Bangun Jejaring," in Republika, edition of March 29, 2017. 
Pitana, I Gde and Putu G. Gaayatri, Sosiologi Pariwisata, Yogyakarta: Andi Publisher, 2005.

Pitana, I Gde dan I Ketut Surya Diana, 2009. Pengantar Ilmu Pariwisata. Yogyakarta: Andi Publisher.

Qardhawi, Yusuf. 1995. Dawr al-Qiyam wa al-Akhlaq fi Iqtishad al-Islami. Mesir; Maktabah Wahbah.

Shihab, M. Quraish, 1993. Membumikan Al-Qur'an Fungsi dan Peran Wahyu dalam Kehidupan Masyarakat. Bandung: Mizan Publisher.

"Ulama dan Ekonomi Syariah: Belajar dari Pengalaman Sudan", in Mokh. Syaiful Bakhri. 2004. Kebangkitan Ekonomi Syariah di Pesantren Belajar dari Pengalaman Sidogiri. Pasuruan: Cipta Pustaka Utama.

“Urgensi Sertifikat Halal.” In Republika, edition of May 12, 2017.

"Wisata Halal, Tumpuan Indonesia," in Republika, edition May 12, 2017. 